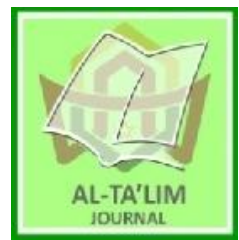

AL-TA'LIM JOURNAL, 27 (1), 2020, (92-102)

(Print ISSN 1410-7546 Online ISSN 2355-7893)

Available online at http://journal.tarbiyahiainib.ac.id/index.php/attalim

\title{
Developing Professional Engagement through ESL Student Teachers' Reflective Writing
}

Received: $29^{\text {th }}$ January 2020; Revised: $16^{\text {th }}$ February2020; Accepted: $27^{\text {th }}$ February 2020

Permalink/DOI: http://dx.doi.org/10.15548/it.v27i1.607

Raja Nor Safinas Raja Harun

Universiti Pendidikan Sultan Idris Tanjung Malim Perak Malaysia

E-mail: nor.safinas@fbk.upsi.edu.my

\begin{abstract}
The objective of this paper is to examine how ESL student teachers identify their own learning needs, analyse, evaluate and expand their professional engagement as an individual or as a community of practice $(\mathrm{CoP})$ through reflective writing. In addition, the written discourses of their reflective entries are studied to illuminate the macro and micro elements of the reflective entries. This study mainly employs a qualitative study with some descriptive quantitative analysis. The participants are 27 ESL student teachers in their $6^{\text {th }}$ semester. The instrument used is primarily the student teachers reflective entries and the content analysis was carried out to analyse for convergent and divergent ideas which were then generated into categories and themes based on the research questions stipulated. The findings revealed that the reflective entries have addressed some pertinent issues related to the student teachers' learning needs and how they have extended their understanding of those issues. The reflective entries discourses have exhibited in-depth professional thinking which served as a platform for student teachers to meta-cognitively think about teaching. This study implicates the importance of such professional learning engagement activity in order to assist student teachers to be thinking about teaching.
\end{abstract}

Keywords: Reflection; ESL student teachers; metacognitive thinking; professional engagement; community of practice and reflective writing discourses.

How to Cite:Harun, R. (2020). Developing Professional Engagement through ESL Student Teachers' Reflective Writing. Al-Ta lim Journal, 27(1). doi:https://doi.org/10.15548/jt.v27i1.607

\section{INTRODUCTION}

Beginning English language
teachers' ability to carry out effective
lessons in the classroom has always been
the topic of discussion among teacher
educators and educationists in general
(Bulut AlBaba, 2017; Kim and Kim, 2017;
Zhukova, 2018). There are many problems
which have been identified and one of
them is the ability for these beginning
teachers to cope with the multi-faceted
lives of classroom situations (Cho, 2017;
Mena, Hennisen and Loughran, 2017).

These problems indirectly point out to the kinds of learning experiences and teacher preparation programs that beginning teachers have gone through (Xiong, 2016). Studies have shown that there are many contributing factors in the teacher education programs that lead to the success or failure of a beginning teacher particularly of those which are related to managing classroom situations (Dirghangi, 2019; Koksel \& Genc, 2019; Franey, 2016). This calls the attention of teacher education programs to review on the kinds of learning experiences that they have 
provided to address issues related to teaching and learning (Cartal \& Basol, 2019; Uzun, 2016; Borg, 2006), and to assist student teachers to prepare and cope with the demand of the $21^{\text {st }}$ century teaching and learning.

In recent years, there is a shift in focus from how teachers teach best to how students can learn best (Banegas, 2016). With the rapid changes of focus on the development on how do students learn best(Urbani, Roshandel, Michaels \& Truesdell, 2017), there is also a demand for teachers to change the way that they teach. In similar vein, teacher educators also need to change the ways of preparing their student teachers in learning how to teach(Munthe and Rogne, 2015).

Since student teachers will be facing classroom situations which cannot be replicated across and within teaching and learning contexts(Mena et al., 2017), there is a need for teacher educators to embark on a transformative kind of pedagogy (Ukpokodu, 2009; Liu, 2015; Ovens, 2017) that would allow student teachers to examine their beliefs, skills and knowledge with the goal of developing reflective knowledge base, an appreciation of multiple perspectives, and a sense of critical consciousness (Ukpokodu, 2009; De Luca (2012); Korocu-Kis and Demir, 2019). This type of learning experiences allows student teachers to reflect and seek for solutions and thus empower them to make relevant decisions in their classroom situations (Zhukova, 2018).

Thus, this paper aims to firstly examine how ESL student teachers identify their own learning needs, analyse, evaluate and expand their professional engagement as an individual or as a community of practice (COP) (Wenger, 1998) through reflective writing. Secondly, it seeks to analyse the macro and micro elements of their reflective entries written discourses.

\section{Reflection in English Language Teacher Education}

Reflection or reflective practice has a long tradition since it was introduced by Dewey (1933) as reflective thinking for personal and professional growth. It was further developed by other researchers using a critical and transformative approach particularly of those rooted in the critical social theory such as Freire (1972), Habermas (1974) and Mezirow (1990). The work of Schon (1983) on reflective practitioner has influenced many scholars especially on how reflection in action and reflection on action can influence the professional education (Moore-Russo \& Wilsey, 2014; Korocu-Kis \& Demir, 2019).

Despite the advantages of integrating reflective thinking into teacher preparation program, many practitioners have argued on how reflection occurs. This is because there are multiple frameworks and there are various levels of reflective thinking or hierarchical levels (Sableski, KinnucanWeslch and Rosemary (2019). These range from descriptive accounts to different levels of mental processing to transformative or intensive reflection (Grossman, 2009; Slate, Burham, Catalina and Waters (2019)). Academic or professional reflection, in contrast to personal reflection, usually involves stated purpose(Moon, 2006; Mena, Hennisen and Loughran, 2017). These various definitions can sometimes contribute confusion at which level of mental processing is account for reflective thinking (Ryken and Hamel, 2016).

Usually being underpinned by a transformative approach (Kalantzis \& Cope, 2008; Liu, 2015), reflective thinking focuses on learners as active participants improving learning and professional practice. Therefore, transformative learning leads to transformation reflection (Ryan \& Ryan, 2012) which involves interrelated ways of knowing through 
understanding of one's own ideologies to broader contextual factors and how they can inform practice. Hence, teacher educators play a critical role in scaffolding and transforming student teachers thinking through dialogic interactions and deliberation as well as constructive feedback.

There are many studies which have focused on the impact of reflection in teacher education (Liu, 2015; Smith and Glend, 2016; Farrell, 2019; Medina, 2020). As an example, Korocu-Kis \& Demir (2019) have done a content analysis of 27 postgraduate studies on reflective practice and English language teacher education (ELTE) in Turkey and have found that reflective practice can benefit ELTE in many ways: familiarizing teachers with reflective practice; promoting collaboration and partnership; and integrating reflective practice as integral part of ELTE.

In addition, Slate et al. (2019) extrapolate that reflective thinking can develop student teachers acquire knowledge and skills in learning how to teach, and this may lead to self-professed changes in personal beliefs systems and world views. In similar vein, such study by Destazi and Esfolian (2018) has revealed that knowledge of professional self, knowledge of learners, knowledge of assessment/testing, knowledge of second language teaching, and knowledge of second language learning sub-component of teachers' professional knowledge based were the best predictors of teachers' reflection. Farrell (2015), as cited in Farell (2019), has proposed a holistic five-phase model which gives focus on teachers exploring their philosophy, beliefs, values, theories, principles, classroom practices and beyond the classroom.

Reflective practice and writing journal entries have been used widely in the teacher education programmers in assisting student teachers to learn how to teach. Besides the general agreement of the benefits of reflection in teacher education, there is a need to explore the dearth of student teachers' reflection and to examine how such practice and learning experiences can assist student teachers in enhancing their professional development as prospective teachers.

\section{METHOD}

This study was a case study of a single site which employed a qualitative analysis of student teachers' reflective entries. It was an on-going study as student teachers were still in their semester of study. There were 28 TESL student teachers who were involved as participants in this study. They were in their sixth semester and were going for teaching practice in their seventh semester.

The participants were undergoing a course entitled 'Instruction, Technology and Assessment 2' which focused on micro and macro teaching, reflective practice and introduction to action research. At the point of this study, the student teachers had written seven entries based on seven micro teaching sessions on the set induction and the presentation stage of their micro teaching. There were two forms of reflective entries that they had written. They either reflected on their own teaching, if it was their turn to do micro and macro teaching in class, or chose a critical situation that they can reflect upon observing other student teachers' teaching.

\section{RESULTS AND DISCUSSION}

From the student teachers' journal entries, it was found that different student teachers had different learning needs because they tend to focus on different situations. Although there were similarities in their choice of critical situations, they tend to personalize learning differently. For example, during the set induction micro teaching session, there were 21 students who submitted their first entry. 
Table 1 describes the distribution of situations in which the student teachers reflected.

Table 1. Distribution of Situations among Participants

\begin{tabular}{c|l}
\hline $\begin{array}{c}\text { No of } \\
\text { Participants }\end{array}$ & \multicolumn{1}{c}{ Situation Reflected } \\
\hline 10 & $\begin{array}{l}\text { Different for each participants such } \\
\text { as questioning techniques, teacher } \\
\text { talk, extended talk, the use of } \\
\text { materials, different level of students, } \\
\text { small talks and turn distributions } \\
\text { Reflection on self-teaching (mostly } \\
\text { based on feedback given) } \\
\text { Using videos as teaching aids } \\
\text { Vocal pace } \\
\text { Did not choose any situation but } \\
\text { merely describing what happened }\end{array}$ \\
\hline
\end{tabular}

Out of the 21 student teachers, many of the student teachers were able to choose the critical situations which they wanted to reflect upon and improve. There were 10 student teachers who chose various incidents to reflect on such as the use of questioning techniques, managing teacher talk, developing extended talk, the use of materials, coping with different level of students, doing small talks and managing turn distributions. There were five students who reflected on their self-teaching based on the comments and feedback received from their course mates and the teacher educator. Three student teachers reflected on using videos as teaching aids and the other two reflected on vocal pace. However, there was one student who did not choose any critical incident but merely described what happened in the class based on what he had observed. This is illustrated in the following reflection.

The lesson began with Sum eye and ended with Sheryl's set induction. Throughout the microteaching for their set induction, I notice several patterns and teaching methods that can be learned and improves. In contrary, I notice several weaknesses and setbacks that can be improved for betterment. (PY, JE1)

Being able to choose a critical incident is perceived as important for student teachers to select an area which is a matter of concern to them. The diverse situations reflected on have shown that different student teachers have different areas of concern which can lead to personal understanding of learning on how to teach. This finding is in congruent with findings from Zia and Yasaman (2018) that teachers' reflection was focused on teacher-related issues such as classroom management, teaching methods and techniques, relationship management, and classroom preparation and these which were labeled as teacher oriented category seemed to be dominant in the teachers' reflective entries.

These understanding can be extended and shared through their reflective entries and read by other course mates. Such practice can enrich the learning experiences of other course mates and better prepared them when facing such situations by connecting to other student teachers experiences. This practice is a meaningful activity for learning to teach as they can explore and learn other student teachers' concerns. Wright (2010) is in support of this finding as one of the goals in second language teacher education is to produce reflective teachers who are able to introspect and collaborate with others in seeing reflective practice as a new learning experience.

This professional development of becoming prospective teachers can be discerned through various situation reflected by the student teachers. For instance, one of the female student teachers has reflected on the distribution of turn taking, the ability to make decisions, establishing authority in the classroom, engaging learners in classroom activities, focusing on teaching points in ensuring learning objectives have been achieved, 
reflecting on self-teaching, and extending talk among learners by asking them to elaborate on reasons. This is illustrated in Table 2.

Table 2. An example of Various Situations Reflected by a Female Student Teacher

\begin{tabular}{|c|c|}
\hline $\begin{array}{l}\text { No of Reflective } \\
\text { Entry }\end{array}$ & Situation reflected \\
\hline Reflective Entry 1 & Distribution of turn taking \\
\hline Reflective Entry 2 & $\begin{array}{l}\text { The ability to make quick } \\
\text { decisions }\end{array}$ \\
\hline Reflective Entry 3 & $\begin{array}{l}\text { Establishing authority in } \\
\text { the class }\end{array}$ \\
\hline Reflective Entry 4 & Engaging the learners \\
\hline Reflective Entry 5 & $\begin{array}{l}\text { Focusing on teaching } \\
\text { points to meet learning } \\
\text { objectives }\end{array}$ \\
\hline Reflective Entry 6 & Reflecting on self-teaching \\
\hline Reflective Entry 7 & $\begin{array}{l}\text { Asking 'why' questions in } \\
\text { the class as a form of } \\
\text { extended talk }\end{array}$ \\
\hline
\end{tabular}

The following illustrates the excerpt from reflective entry 7 .

In her micro teaching today, my friend always ask the students 'Why' questions... I realized that there are advantages if ...One of it is allowing the students to think deeper. Not only asking the students to give answers or examples but also ask the students to analyze and explain their answer. It will eventually allow the students to think deeper or recall their previous knowledge about that particular lesson...it can also promote interactionin class. When my friend asked ...she was actually trying to extend the talk and avoid unnecessary teacher talk. As I reflect, I tend to do excessive teacher talk...(AA, JE 7)
The ability for student teachers to reflect on diverse situations was a proof that student teachers were capable to identify areas of concerns and they were critical when observing other student teacher's teaching. In support of this finding, Cho (2017) in her study has found that reflective practice can help student teachers to be thinking and developing like experienced teachers (Farrell, 2019).

The description of the situations in critical reflection required them not to only describe the situations but they also need to make pedagogical assumptions as to why the situations occurred and what evidences that they had observed to support their assumptions. This indirectly got the students teachers to be involved in deep structure learning which can enhance and extend their thinking in matters relating to learning how to teach.

The 5R, reporting, responding, relating, relating, reasoning, reconstructing, levels of reflection by Bain et al. (2002) were used as the basis for analyzing how student teachers analyzed, evaluated and expanded their understanding in the reflection process. To ease the process of analysis, the 5Rs'levels were categorized into three categories which were descriptive situations, analysis of situations and solutions as shown in the table 3 .

Table 3. Combination of Levels of Reflection into Categories

\begin{tabular}{cc}
\hline $\begin{array}{c}\text { 5R's Level of } \\
\text { Reflection } \\
\text { (Bain et al., 2002) }\end{array}$ & $\begin{array}{c}\text { 3 Categories of } \\
\text { Reflection }\end{array}$ \\
\hline Reporting & Descriptive \\
Responding & Analysis \\
Relating & \\
Reasoning &
\end{tabular}

Reconstructing Solution

As illustrated in the table 3, reporting and descriptive is the level in which student teachers established the situation which they had chosen to reflect 
upon. This includes describing what had occurred in the classroom as exemplified in the following example by one of the student teachers journal entries. Many of the student teachers did not encounter any problem at this level as they were able to identify situations to reflect upon.

On the $10^{\text {th }}$ of March, 4 students presented their microteaching for the explanation stage. Each person used different types of methods and materials to present their microteaching. Hence, it provided an interesting experience to us as we got to see the similarities and differences of one student teacher to another. One of the incidents that $I$ found to be interesting is the use of creative and relatable activities. This was because one of the students used cartoon cut outs to introduce feelings and it was very much relatable that even young adults were engaged in the activity.

(HS, JE 4)

The responding, relating and reasoning levels by Bain et al. (2002) were categorized as the analysis made by student teachers to think deeper and make pedagogical assumptions on the situation reflected. Many of the student teachers were able to analyzed the situation further. However, the only limitation identified at this level was the ability to explain and interpret the situations explicitly. It was noticed that student teachers with good writing proficiency were able to use precise language and made their interpretation explicit as shown in the following example. On the other hand, student teachers with less writing proficiency tend to use wrong choice of words and sentence structure and lack of coherence between ideas.
In accordance to the above findings, Slade et al. (2019) have found that approximately about $25 \%$ of their student teachers' reflections are at the lowest level, or habitual action level; more than half $(56 \%)$ of them are at understanding level; and very few of their student teachers wrote reflections at the higher levels of reflection $(18 \%$ at level three and $1 \%$ at level four).

The following excerpt is a continuation at the analysis level of the same reflective entry as above.

Based on my opinion, I feel
that it is important for a
teacher to come up with
activities that can draw the
students' interest. In order to
encourage student engagement
in the classroom, the teacher
needs to be innovative in
preparing activities that are both
fun and relatable to introduce
a certain topic. For instance,
the teacher can use games while
teaching on the topic of
proverbs. Even though it is
important for a teaching point
to be delivered to the students,
it can be done by carrying
activities that are interactive
and encourages active learning
in the classroom.

The phrases use like 'based on my opinion' indicates the student teachers ability in analyzing the situations based on her perspectives. The use of pronoun 'I' indicates the personal views which student teachers have in analyzing the situations. The student teacher has also provided an example used by the student teacher she observed. She related this to her views that although it is important to deliver a teaching point through activities, which she has found as interactive and can promote active learning. 
The ability to analyse situations observed and to interpret those situations are important aspects of doing reflection as student teachers can relate their pedagogical knowledge which they had acquired through the courses into pedagogical understanding and practice. This finding concurs with the findings of Estaji and Dezfoolion (2018) who have found that there is a significant relationship between EFL teachers' professional knowledge base and their reflection. In extension, they found that knowledge of professional self, knowledge of learners, knowledge of assessment/testing, knowledge of second language teaching, and knowledge of second language learning sub-component of teachers' professional knowledge base were the best predictors of teachers' reflection.

At the reconstructing level or problem solutions, student teachers are required to find innovative solutions to the situations which they had reflected on as described in the following:

\section{As a future teacher, I should use fun activities in my classroom such as games. According to Ghazal and Singh (2016), games in the classroom will be able to promote student-centered learning, promote engagement and encourage motivation. In order to ensure students are undergoing an enjoyable process during the teaching and learning process, I will need to be more flexible and creative with my teaching style.}

Based on the excerpt above, it was noticed that the student teacher was relating to her future situations as prospective teachers. She stated agreement on the use of fun activities and more importantly relate to a relevant source on the benefits of promoting such learning. She also indicated the action which she should consider, that is to become more flexible and creative, if she wanted her students to go through an enjoyable process of learning.

This level is the most difficult level for many student teachers as they were not able to pose tangible solutions to the situations they had reflected. Most of the student teachers did not cite any relevant sources to support their solutions and many of the solutions were quick decisions and were mentioned briefly without any support as shown in the following excerpt:

A few suggestions I can create
from this lecture and the
microteaching sessions are to
have organized materials, be
careful with pronunciation, be
confident while teaching, use a
louder voice, and choose
materials according to the
student's proficiency level.

In argument to the above findings, Liu (2015) has found that it is important for all insights reflected to end with an action based so that student teachers can examine the effects of their actions.

The above excerpt indicated that in such situation in which student teachers did not deal with in-depth thinking of their problem solutions and did not refer to relevant sources, there is a possible tendency for them not to be able to expand their professional understanding of what they already know. Such student teachers require further coaching as this finding reveals the incapacity of fulfilling the essentials in a teacher education preparation for nurturing deep thinking and critical self- reflection (Ricardo, 2020).

To ensure transformational learning happens, there is a need for reconstruction of knowledge among the student teachers. Therefore, their pedagogical understanding can be scaffold from existing knowledge to new understanding. Liu (2015) supports the idea that transformative learning 
requires critical reflection that challenges or negates values that are close to the reflecting student teacher self-conception.

Most reflective entries were found to have developed from descriptive to more analytical kind of writing with the guidance and feedback given to the student teachers either from the teacher educator or their course mates. However, this is in contrast with a study by Ulusoy (2016) who found that although his student teachers have increased their reflection levels, only $3.92 \%$ of the pre service teachers written reflections reached the transformative level and technical reflections $(46.58 \%)$ were the most frequently seen level in pre-service teachers written samples.

The micro analysis of the discourses in the reflective entries was carried out to examine how the student teachers' displayed their metacognitive pedagogical understanding through the written reflective entries. In addition, it was carried out to see the kind of words or phrases used to describe metacognitive professional understanding of learning how to teach. Among the frequent phrases, which were used throughout the reflective entries to show metacognition at different points of the reflection, depending on individual's student reflections are: display pedagogic understanding; short and meaningful, long and engaging; automaticity; opportunities for students to speak; classroom control; acknowledged every responses; structuring questions; equal opportunities; full engagement; excessive teacher talk; distributing talk; extending the talk; ability to think on your feet; and allocating turn taking.

The aforementioned phrases used positively indicated that student teachers were reflective towards the feedback given by the teacher educator who made use of these phrases when giving feedback to the student teachers' teaching. The ability to use such phrases suggests that student teachers were able to display their metalanguage of pedagogical understanding of learning how to teach. In favour of this finding, Sableski et al. (2019) has elucidated that the reflection process can be seen as a metacognitive process which bring coherence to an initially coherent situation; involve complex interplay between of observation and inference as well as point forward for future actions.

All the above findings have shown that such learning experiences can be meaningful to be integrated in a teacher education program for student teachers to make sense of their own learning and how those experiences can transform to lifelong endeavors as prospective teachers. Kubanyiova (2018) argues that student teachers making sense of their learning experiences during preparation program is crucial in shaping them to become remarkable teachers. In extension, in support of the above findings, Farrell (2019 have agreed that reflective practice should transform student teachers to become active mediators of their own learning. This can be seen through the findings in which student teachers have contested their beliefs and classroom practices and took responsibility of their own professional development.

\section{CONCLUSION AND RECOMMENDATION}

This study has shed lights on how the use of reflective entries in pedagogical courses can develop professional engagement among ESL student teachers. Although there are many literatures in the past which have debated that professional understanding can never be fully developed until a student teacher has been in the real situation of teaching and partially during placement of their teaching practice. However, this study has indicated that professional engagement can be nurtured by getting student teachers to be thinking and reflecting on their understanding of 
learning how to teach. The analysis of student teachers entries can help inform their pedagogic understanding on how they can learn to teach. Learning from each other's experiences and perspectives can enrich their understanding by sharing their entries with constructive feedback, facilitation and support from the teacher educator.

On the other hand, teacher educators can develop consciousness of student teachers' professional knowledge based as different student teachers may reflect and bring into discussion different sorts of knowledge and insights to the teacher education context. Thus, the recognition of both knowledge based and reflection can nurture further understanding of pedagogical development. This study implicates the needs for teacher education courses to be transformative learning in nature and to get student teachers to be involved in deep thinking that can help develop their professional and pedagogical understanding of teaching.

\section{REFERENCES}

Banegas, L.D. (2016). Exploring perceptions of curriculum change in initial English language teacher education: A case in Argentina. Estudios Sobre Educacion. 31 (1), 75-95. DOI: 10.15581/004.31.75-95.

Borg, S. (2006). The distinctive characteristics of foreign language teachers. Language Teaching Research, 10(1), 3-31.

Bulut Albaba, M. (2017). Teacher learning during transition from pre-service to novice EFL teacher: A longitudinal study. Novitas-ROYAL. 11 (2), 142154.

Cartal, G. \& Basol,H.C. (2019). Generic teacher competencies and the English Language teacher education program in Turkey. Novitas-ROYAL. 13(2), 133-154.
Cho, M. (2017). Pre-service L2 teacher trainees' reflections: what do they focus on? English Teaching, 72(1), 105-129.

DeLuca, C. (2012). Promoting inclusivity through and within teacher education programmes. Journal of Education for Teaching: International Research and Pedagogy, 38(5), 551-569.

Dewey, J. (1933) How we think: A restatement of the relation of reflective thinking to the educative process. Boston, MA, USA: DC Heath.

Dirghangi, C. (2019). Mindful self-inquiry: preventing burnout in preservice English Teachers through a tailored mindfulness-based curriculum. The Virginia English Journal. 69(1), 7278.

Estaji, M. \& Dezfoolian, S. (2018). EFL teacher's pedagogical knowledge base as a predictor of teacher's reflectivity: Comparing different components and perceptions. International Journal of Instruction. 11 (3), 491-510. DOI: 10.12973/iji.2018.11334a.

Farrell, T.S. C. (2019). 'My Training Has Failed Me': Inconvenient Truths About Second Language Teacher Education (SLTE). TESL-EJ. 22 (4), 1-16.

Franey, J. J. (2016). Understanding teacher development theories. Developing Difference Makers. Retrieved from https://www.developingdifferencema kers.com/educationblogs/april-12th201611

Freire, P. (1972). Pedagogy of the Oppressed. New York: Penguin Books.

Grossman, P. (2009). Structures for facilitating student reflection. College Teaching. 57(1), 15-22. 
Habermas, J. (1974). Theory and Practice. London: Heinemann.

Kalantzis, M. \& Cope, B. (2008) New Learning: Elements of a science of education. Cambridge: Cambridge University Press.

Kim, K., \& Kim, J. (2017). Going beyond the gap between theory and practice: Rethinking teacher reflection with poststructural insights. Journal of Early Childhood Teacher Education. $38 \quad$ (4), 289-307. DOI: 10.1080/10901027.2017.1388307.

Köksal, D. Genç, G. (2019). Learning while teaching: Student teachers' reflections on their teaching practicum. Journal of Language and Linguistic Studies, 15(3), 895-913. DOI: $10.17263 /$ jlls.631531

Korucu-Kis, S. \& Demir, Y. (2019). A review of graduate research on reflective practices in English language teacher education: Implications. Issues in Educational Research. 29(4), 1241-1261.

Kubanyiova, M. (2018). Language teacher education in the age of ambiguity: Educating responsive meaning makers in the world. Language Teaching Research. https://doi.org/10.1177\%2F13621688 18777533.

Liu, K. (2015). Critical reflection as a framework for transformative learning in teacher education. Educational Review, 67(2), 135-157.

Mena, J., Hennissen, P. \& Loughran, J. (2017). Developing pre-service teachers' professional knowledge of teaching: The influence of mentoring. Teaching and Teacher Education, 66, 47-59.

Mezirow, J., \& Associates (1990). Fostering Critical Reflection in Adulthood: A Guide to Transformative and Emancipatory
Learning. San Francisco, CA: Jossey-Bass.

Moon, J. A. (2006). Learning Journals: A Handbook for Reflective Practice and Professional Development. $2^{\text {nd }}$ ed. London, UK: Routledge.

Moore-Russo, D. A. \& Wilsey, J. N. (2014). Delving into the meaning of productive reflection: A study of future teachers' reflections on representations of teaching. Teaching and Teacher Education. 37, 76-90. https://doi.org/10.1016/j.tate.2013.10 .002 .

Munthe, E., \& Rogne, M. (2015). Research based teacher education. Teaching and Teacher Education, 46, 17-24.

Medina, R. A. (2020). Designing, facilitating, and supporting for the critical engagement of selfreflection, critical diaglogue, and justice-oriented teaching. Teacher Education Quarterly. 47(1), 117-122.

Ovens, A. (2017). Putting complexity to work to think differently about transformative pedagogies in teacher education. Issues in teacher education, 26(3), 38-51.

Ryan, M. \& Ryan, M. (2012). Theorising a model for teaching and assessing reflective in higher education. Higher Education and Reflection Development, 32 (2), 1-14.

Sableski, M., Kinnucan-Welsch, K., \& Rosemary, C. (2019). Facilitating teacher reflection using a metacognitive tool. Mid-Western Educational Researcher, 31 (3), 312332.

Schon, D. (1983) The Reflective Practitioner: How Professionals Think in Action. New York: Basic Books.

Slade, M.L., Burnham, T. J., Catalana, S. M., \& Waters, T. (2019). The impact 
of reflective practice on teacher candidates' learning. International Journal for the Scholarship of Teaching \& Learning. 13 (2), 1-8. DOI: $10.20429 /$ ijsotl.2019.130215.

Smith, M. D., \& Glenn, T. L. (2016). Reflecting on the reflection: exploring teacher candidates' assumptions of self and others through facilitated reflection. Teacher Educator. 51 (4), 314-334. DOI: 10.1080/08878730.2016.1195468.

Ukpokudu, O. (2009). The Practice of Transformative Pedagogy. Journal of Excellence in College Teaching. 20(2), 43-67.

Ulusoy, M. (2016). Field experiences in teacher education: the perceptions and qualities of written reflections. Teaching in higher education, 21(5), 532-544.

Urbani, J.M., Roshandel, S., Michaels, R., \& Truesdell, E. (2017). Developing and modeling $21^{\text {st }}$ century skills with pre-service teachers. Teacher Education Quarterly, Fall, 27-50.

Uzun, L. (2016). Evaluation of the latest English language teacher training programme in Turkey: Teacher trainees' perspective. Cogent Education, 3(1), 1147115.

Wenger, E. (1998). Communities of Practice: Learning, Meaning and Identity. New York: Cambridge University Press.

Wright, T. (2010). Second language teacher education: Review of recent research on practice. Language Teaching. 43(3), 259-296.

Xiong, Z. (2016). The impact of teacher education on in-service English teachers' beliefs about self. Journal of Language Teaching and Research, 7(3), 519-526. http://dx.doi.org/10.1750/jltr.0703.12
Zia Tajeddin \& Yasaman Aghabadazadeh. (2018). Blog mediated reflection for professional development: exploring themes and criticality of L2 teachers' reflective practice. TESL Canada Journal. 35(2), 26-50.

Zhukova, O. (2018). Novice teachers' concerns, early professional experiences and development: Implications for theory and practice. Discourse and Communication for Sustainable Education. 9(1), 100114. 